\title{
Introduction
}

The small northern highland town of Lalibela is Ethiopia's single most important Christian pilgrimage site, mainly because of its 12 rock-hewn churches from the twelfth century. Remotely located at an elevation of 4,500 metres, the town had been difficult to access by road until an airstrip, serviced by a domestic connection from Addis Ababa, was opened in 1959. While interested foreign visitors sometimes had made their way to Lalibela since then, a big change was underway from 1965 on. In that year, Princess Ruth Desta, granddaughter of Ethiopian Emperor Haile Selassie I, arrived in Lalibela, entrusted by the emperor to supervise and accelerate the construction of the Seven Olives Hotel, the first high class hotel in the region, and the first to accommodate tourists rather than pilgrims, for it to be completed in time for the visit of Queen Elizabeth II in February 1965. Once completed, Swedish and American missionaries were put in charge of managing the hotel project. Unfortunately, the Queen's visit to Lalibela was suspended after the Queens Flight deemed the rugged, unpaved airstrip as not safe enough for a royal visit. Despite this, the preparation of tourist infrastructure and promotion of Lalibela as a tourist attraction were successful and 1965 marked the year of an ever-increasing influx of international tourists to the town. During the months she spent in Lalibela, Princess Ruth committed herself not only to the hotel project but also to the restoration of the churches, which were difficult to access, and heavily affected by centuries of rainfall that had been eating away the delicate sandstone, and a large-scale international restoration project started in the same year. It was in fact a collaborative effort between the International Center for the Conservation and Restoration of Monuments (ICCROM) and the US-based International Fund for Monuments, and dispatched a number of European conservators and technicians under the guidance of an Italian architect-restorer. The funds and expertise came from these organisations, while the Ethiopian government administered the projects. ${ }^{1}$

This first project was the overture to 20 years of extensive international cultural and natural conservation projects in Ethiopia, funded and expertly managed by foreigners commissioned by the Ethiopian government, culminating in the awarding of the title of UNESCO World Heritage to seven Ethiopian heritage sites between 1978 and 1980. The number of heritage sites was remarkable

1 Cheques and spreadsheets in NALE, 1.2.26.5, Lalibela Committee; International Fund for Monuments, Lalibela-Phase I: Adventure in Restoration (New York: International Fund for Monuments, 1967); Ivy Pearce, An Ethiopian Harvest: A Collection of Experiences Garnered (Worthing: Churchman, 1988), 116-18.

Ә OpenAccess. () 2021 Marie Huber, published by De Gruyter. (cc)BY Creative Commons Attribution 4.0 International. https://doi.org/10.1515/9783110681017-003 
then, in the first years of the World Heritage Programme, and is now, for an African country anyway. The mise-en-valeur of the Lalibela churches and other Ethiopian monuments for touristic purpose and representative state visits demonstrated at once the glorious past and the progress underway in Ethiopia, and turned Lalibela and other heritage sites into a stage to showcase the past, present and future of the nation. Antiquities and, in a similar manner, the Ethiopian highlands, at that time, were not only established as the official national heritage; they became one of Ethiopia's most valuable assets, or patrimonial resources. $^{2}$

The story of Ethiopia's national heritage and its making with the help of foreign and international aid during the 1960s and 1970s sits right at the centre of politically, socially and economically turbulent times. It is not possible to comprehend Ethiopian nationalism and its relevance for internationalism without understanding how developmental and national identity politics were related, and how ideas of progress and history were constructed and instrumentalised by the governing elites.

More broadly speaking, I want to show that through national heritage, the International materialised in the developing world, during the what can be called the modernist, foreign aid era of development during the 1960s and 70s of the twentieth century. More specifically, my aim with this book is to show that the making of World Heritage happened intertwined with national heritage and how development thinking was conducive to the politicisation of heritage in a developing country.

The international involvement in the conservation of Lalibela and other Ethiopian heritage sites was part of a global process, the colluded rise of the concept of universal heritage and national heritage, catalysed through international organisations, at a time when the importance of Africa and African countries in the world shifted towards a new role. A place where this was most significant and evident is Ethiopia. Understanding the links between Ethiopia, UNESCO and the World Heritage programme during its initial phase provides insights into the complex processes of knowledge production of nation-states in the new international world order shaping up during the "Global Sixties".

The modern Ethiopian state came into being when, from 1889 on, Emperor Menelik II built diplomatic relationships with Europe to acquire technology and expertise, secured the international recognition of Ethiopian sovereignty and expanded the state territory into the south. The nation and its boundaries would

2 Lisa Breglia, Monumental Ambivalence: The Politics of Heritage (Austin: University of Texas Press, 2006), 30. 
remain fragile and a threat to government integrity and state power for the following decades, and references to the past were invoked to stabilise the rule over Ethiopia. When the prince regent Ras Tafari was crowned as Emperor Haile Selassie I in 1930, he legitimised his rule with references to the 3000-year-old Solomonic, biblical tradition, an image he knew would resound well with the international political stage and in return strengthen his interior position as a central power in opposition to the ruling Ethiopian elites of princes and landowners. After the military revolution in 1974, the socialist Derg renounced the more recent past as a feudal, centralist and absolutist period, but propagated the Pan-Ethiopian empire and its historical continuity, underpinning a violent and expansionist authoritarian rule that lasted until 1991.

This official version of Ethiopian national identity was not only subject to political tactical and strategical manoeuvres of the government. At the same time, Ethiopia became a very important symbol in the African decolonisation and nation-building process as well as in internationalist movements of Pan-Africanism, the Non-Aligned-Movement and Communist-Marxist Internationale. Ethiopia's supposed historical exceptionalism as Africa's longest-lasting empire and ancient civilisation provided a strong counter-narrative to the colonial paradigm of the impossibility of self-rule for contemporaries in the 1960s from within and external to Ethiopia, and Ethiopian nationalism constituted the new African political nationalisms, as well as Pan-Africanism, during that time to a significant degree. Ethiopian history, in this understanding, alluded to key features for nation-state-building that were thought to be missing in other African countries: a tradition of sovereign rule.

As I will show, the conservation efforts in Lalibela, orientated towards its accessibility for an international audience, were part and parcel of the Ethiopian nation-building process, not only because they framed an existing religious heritage site and lieu de mémoire as national heritage. They demonstrate that heritage conservation was not only a technical matter, but also included the allocation and management of resources. ${ }^{3}$ Conserving the monuments in Lalibela as national heritage was part of a state-building and modernisation process, constituted of development-led thinking and planning, which ensured that the nationstate-building in Ethiopia happened on the terms of those in power. During the 1960s, the development paradigm superseded other issues in global policy and

3 William Logan, Michele Langfield, and Máiréad Nic Craith, "Intersecting Concepts and Practices", in Cultural Diversity, Heritage and Human Rights: Intersections in Theory and Practice (Abingdon, Oxon; New York, NY: Routledge, 2010), 17-18. 
development planning dominated the political language in African countries. ${ }^{4}$ The conservation of monuments and nature involving UNESCO during the 1960s and 1970s delivered a legal instrument for exclusion and repression of ethnic and cultural groups, for threatening livelihoods, by allowing the Ethiopian government to map national claims over existing territories.

It is easily overlooked that, contrary to the role of Ethiopia as a symbol in the anti-imperial struggle, the Ethiopian state was in itself a colonising empire. Ethiopian historiography was dominated by the idea of a greater Ethiopian state, including the territories of Eritrea and the Ogaden region inhabited by Somali people, located in the East of Ethiopia at the Ethio-Somalian border. Throughout the twentieth century, this idea of a greater Ethiopian state was utilised and conceptualised within the political framework of establishing Ethiopian imperial rule. Western and Ethiopian scholars and intellectuals alike produced a dominant version of Ethiopian history which in the 1980s began to be challenged by a re-reading from the periphery, through the emerging fields of Oromo, Somali and Eritrean studies. Institutional heritage-making in Ethiopia therefore had a decidedly international dimension and the political dimensions of national heritage in Ethiopia relate to the historiography and political thinking in Ethiopia throughout the twentieth century. ${ }^{5}$

Even though it has been widely discussed how students and peasants, especially those from southern Ethiopia, mobilised the national question in pre-revolutionary and revolutionary Ethiopia, we know very little about the institutional response to these positions. State institutions concerned with implementing national and international policies considerably shaped the imaginaries underwriting the intellectual discourse of Ethiopian nationalism. Today, after decades of history writing under strong state censorship, the ethnic federalism politics of the past 20 years gave way to histories of the contestants of Ethiopian identity, and their ethnic nationalisms, be they Tigrean, Oromo or Amhara, calling for a deeper investigation of the politicised nature of the official Ethiopian heritage and the Ethiopian World Heritage sites. ${ }^{6}$ I hope to contribute to these recent his-

4 Andreas Eckert, “”We Are All Planners Now.” Planung und Dekolonisation in Afrika”, Geschichte und Gesellschaft 34, no. 3 (2008): 396.

5 Sara Marzagora, "History in Twentieth-Century Ethiopia: The "Great Tradition" and the Counter-Histories of National Failure”, The Journal of African History 58, no. 3 (November 2017): 425-44; Alessandro Triulzi, "Battling with the Past: New Frameworks for Ethiopian Historiography”, in Remapping Ethiopia: Communism and After, ed. Wendy James, Donald L. Donham, and Elsei Kurimoto (Oxford; Rochester, NY: James Currey, 2002), 280-85.

6 Pietro Toggia, "History Writing as a State Ideological Project in Ethiopia”, African Identities 6, no. 4 (2008): 319-43, https://doi.org/10.1080/14725840802417869; Bahru Zewde, “A Century of 
toriographies of Ethiopian nationalism by analysing a set of institutions and their engagement with foreign and international actors, to show how much Ethiopian nationalism was comprised of validation through internationalist and Western frameworks.

Furthermore, many studies of the history of the Ethiopian state focus on ruptures, crises and conflicts. ${ }^{7}$ A more extensive institutional history of the Ethiopian state has yet to be written, but the investigation of the two (natural and cultural) conservation authorities as well as the analysis of government publications aimed at an international audience in this book demonstrate that this history is one of a continuous evolution running steadily (and in parts unaffected) under the rough political current. To better understand this history of Ethiopian state institutions, I suggest that the state-building process has to be analysed vis-a-vis the nation-building process - and as one that took place during a time when new international ideas and institutions became more relevant than ever, during the beginning of the Global Cold War, decolonisation and the end of empire. ${ }^{8}$ If nation-building, as some argue, is the establishment of a national identity aimed at constructing the cultural legitimacy of a country, I argue it functioned as the front end of the new internationalisms. And to keep with the metaphor, I suggest to think of state-building, meaning the establishment of a bureaucratic infrastructure, and means of governance beyond the state administration, as the back end. ${ }^{9}$ In Ethiopia, where no frame of bureaucracy and administrative infrastructure had been left behind by a colonial power, the lack of state bureaucracy presented a significant obstacle towards the implementation of international assistance programmes. Building an administrative and bureaucratic infrastructure was a key element of Haile Selassie I's imperial consolidation pol-

Ethiopian Historiography”, Journal of Ethiopian Studies 33, no. 2 (2000): 1-26; Christopher S. Clapham, "Rewriting Ethiopian History”, Annales d'Éthiopie 18, no. 1 (2002): 37-54, https:// doi.org/10.3406/ethio.2002.1013.

7 Donald Nathan Levine, Greater Ethiopia: The Evolution of a Multiethnic Society, 2nd ed. (Chicago; London: University of Chicago Press, 2000); Alain Gascon and Roland Pourtier, La Grande Éthiopie, une utopie africaine. Éthiopie ou Oromie, l'intégration des Hautes Terres du Sud (Paris: CNRS, 1995); Wendy James et al., eds., Remapping Ethiopia: Socialism and After (Oxford: James Currey, 2002).

8 Glenda Sluga and Patricia Clavin, "Rethinking the History of Internationalism”, in Internationalisms: A Twentieth-Century History, ed. Glenda Sluga and Patricia Clavin (Cambridge; New York: Cambridge University Press, 2017), 4-5.

9 Jeffrey James Byrne, Mecca of Revolution: Algeria, Decolonization, and the Third World Order (Oxford; New York: Oxford University Press, 2016), 8; Béatrice Hibou, The Bureaucratization of the World in the Neoliberal Era: An International and Comparative Perspective (New York: Palgrave Macmillan, 2015), 10. 
itics, and many ministries and state departments were built up during the 1960s with the help of bilateral and international assistance. The Ethiopian heritage institutions are exemplary of the huge scale of institutionalising and indigenising Western knowledge production and state bureaucracy in developing countries that started in the 1960s, facilitated by the UN.

Development and the concept of raising and levelling standards of living on a global scale was part of the UN founding idea, and was inspired by three main concerns and experiences. ${ }^{10}$ Firstly, European post-war reconstruction and, secondly, an overall technocratic thinking that had extended its reach into the economic sphere, and which became prominent during the financial strains of both world wars. Thirdly, the debates surrounding the increasing instability and difficulties of European colonial politics were important conceptual building blocks for the particular concept of development as it should unfold as a major concern of the UN. The aforementioned aspects of development as a reconstruction effort, and development as a technical solution to social problems, thereafter connected "the economies of European reconstruction and the geography of colonial development". ${ }^{11}$ The notion of underdevelopment quickly diversified into the distinction between economic weakness as a consequence of war, and the more structural weakness that resulted from colonisation or was declared to be rooted in a general under-civilised state of some societies, in effect continuing colonial argumentations. Technical internationalism became a new political action framework that looked towards social engineering and interventionist economic policies as a pathway to prosperity. ${ }^{12}$

10 For a history of the term development see: Albert Sanghoon Park, "Does the Development Discourse Learn from History?”, World Development 96 (2017): 52-64; for an overview of the UN-System and development see: Amy L.S. Staples, The Birth of Development: How the World Bank, Food and Agriculture Organization, and World Health Organization Have Changed the World, 1945-1965 (Kent, OH: Kent State University Press, 2006); Olav Stokke, The UN and Development: From Aid to Cooperation (Bloomington: Indiana University Press, 2009); and Marc Frey and Sönke Kunkel, "Writing the History of Development: A Review of the Recent Literature”, Contemporary European History 20, no. 2 (2011): 215-32, https://doi.org/10.1017/ S0960777311000075.

11 Daniel Speich Chassé, "Technical Internationalism and Economic Development at the Founding Moment of the UN System”, in International Organizations and Development, $1945-$ 1990, ed. Marc Frey, Sönke Kunkel, and Corinna R. Unger (Basingstoke: Palgrave Macmillan, 2014), $23-45$.

12 Gilbert Rist, The History of Development: From Western Origins to Global Faith, trans. Patrick Camiller, 3rd ed. (London; New York: Zed Books, 2008); Speich Chassé, “Technical Organizations", $30-32$. 
In the process of decolonisation, many new states joined the UN System and caused the UN to undergo a metamorphosis during this decade, when these socalled developing countries gained a majority representation in the UN General Assembly and presented a Third World bloc that acted as an "alternative 'we' to both imperial incorporation and national separation". ${ }^{13}$ This new majority pushed for a programmatic shift towards development as empowerment and as a major responsibility of the international community, coining the 1960s the First UN-Development Decade. According to this new understanding of development, the UN was supposed to provide mainly technical and request-driven assistance through their specialised agencies and replace the earlier top-down and donor-driven aid programmes.

It is within this framework that the notion of development as a predominantly economic enterprise was conceived, and visions of the future shifted from technocratic, social-engineering solutions towards an idea that providing funds and knowledge would help the states "develop" solutions by themselves. This notion would dominate development policies and actions for the following decades. After 1955 there were no specialised agencies or organisations in the UN system whose programmes were not permeated in some way with the concern for economic development. Some, like the World Bank, simply turned into development agencies. ${ }^{14}$ Others contributed to relevant policymaking within their areas of specialisation. The development decade resulted in a large-scale expansion of a global development-industry, as the UN resolutions resulted in a re-framing of existing initiatives.

In 1966, the UNDP was founded in an attempt to merge existing development programmes and to streamline and prioritise the UN assistance programmes according to the new development paradigm. The UNDP was supposed to act in a coordinating role, distributing existing funds among the UN specialised agencies, among them UNESCO, as well as running separate programmes specific to more acute concerns. Nearly all UN activity in the new developing countries became the domain of UNDP, ${ }^{15}$ including the follow-up project to the first restoration efforts in Lalibela, which entailed the conservation of a larger number of Ethiopian monuments. Fostering economic development through tourism to her-

13 Frederick Cooper, “Writing the History of Development”, Journal of Modern European History 8, no. 1 (2010): 17; Chloé Maurel, Histoire de l'UNESCO: Les trente premières années. 1945-1974 (Paris: L'Harmattan, 2010), 141-42.

14 Michele Alacevich, The Political Economy of the World Bank: The Early Years (Stanford, CA; Washington, D.C.: Stanford Economics and Finance; World Bank, 2009).

15 Craig N. Murphy, The United Nations Development Programme: A Better Way? (Cambridge: Cambridge University Press, 2006), 78-79, https://doi.org/10.1017/CBO9780511618000. 
itage sites was introduced as the key reason to provide funds for this project, which considerably accelerated the conservation of selected sites and monuments. As a part of this project, international experts, sent by UNESCO, manned the departments for cultural heritage and wildlife conservation, drafted legislation, inventoried antiquities, mapped national parks and prepared the World Heritage nomination for submission to UNESCO. How much the UN special agencies and their experts were a formative influence for the state- and nation-building process can be studied in Ethiopia, where a dense layer of experts was woven into the growing Ethiopian state-bureaucracy, to be found in every sector of government activities, most of them dispatched by a UN special agency, be it UNESCO, FAO, WHO or others.

As outlined above, from their inception, development efforts were characterised by technocratic and paternalistic thinking, by the act of defining others as deficient and being entitled to know how they can be helped, causing an inherent structural hegemony of the very concept of technical assistance. ${ }^{16}$ Development shares several characteristics to the discourse identified as Orientalism by Edward Said, in producing, from the standpoint of an assumed Western cultural hemisphere, realities of the world that dictate "politically, sociologically, ideologically, scientifically, and imaginatively." gaged in and further advanced this mode of systematising the world in Western terms, rendering Africa, Asia and Latin America into underdeveloped representations of Europe and North America. To show the power dynamics underpinning both the discourse and practice of development, the manifold activities labelled as or identified as development cooperation have to be analysed by combining the study of the concepts, institutions and theories with the study of their implementation, meaning the activities and projects that took place as development efforts as well as mapping the stakeholders and looking at the way they talked about it. ${ }^{18}$

16 Frederick Cooper, “Modernizing Bureaucrats, Backward Africans, and the Development Concept", in International Development and the Social Sciences: Essays on the History and Politics of Knowledge, ed. Frederick Cooper and Randall Packard (Berkeley, CA: University of California Press, 1997), 64-92; for a more recent state of the debate see Emmanuel Akyeampong et al., eds., Africa's Development in Historical Perspective (New York: Cambridge University Press, 2014).

17 Edward W. Said, Orientalism (New York: Vintage, 1979), 3.

18 Hubertus Büschel and Daniel Speich, "Konjunkturen, Probleme und Perspektiven der Globalgeschichte der Entwicklungszusammenarbeit”, in Entwicklungswelten: Globalgeschichte der Entwicklungszusammenarbeit (Frankfurt a. M.: Campus, 2009), 9. 
Since the 1970s, critical positions have been established, arguing that development in the international system effectively was a neo-colonial effort, identifying many of the same mechanisms and effects that had characterised colonial control. ${ }^{19}$ Recent historical studies of development planning and politics, however, show that they were also utilised in many African countries by political elites to reinforce the nation-state-building as well as acquisition of funds for the benefit of the few rather than the many. I want to support these findings by shifting attention from the dichotomy of Western and non-Western, developed and underdeveloped, hegemony and dependency to the complex power dynamics and relationships at play behind development projects. Following heritage-making, state-modernisation and development, I argue, connects actors and institutions historically in a shared process of knowledge-production and world-making.

Many works analysing the impact of global heritage policies and international organisations on a local level suffer from ascribing agency to an international organisation, such as the UN, but even more so for the UN special agencies such as UNESCO, in their totality. ${ }^{20}$ International organisations were from the beginning not only political arenas or diplomatic stages, but also large-scale bureaucracies $^{21}$ and derived much of their authority from expertise and operated on the basis of rules that experts had defined. ${ }^{22}$ Recent historiographies of international organisations analyse them as knowledge-producing institutions, with a special focus on experts that fulfilled a crucial role as brokers and mediators between

19 Walter Rodney, How Europe Underdeveloped Africa (London; New York: Verso, 2018); Arturo Escobar, Encountering Development: The Making and Unmaking of the Third World (Princeton, NJ: Princeton University Press, 2012).

20 Christoph Brumann and Lynn Meskell, "UNESCO and New World Orders”, in Global Heritage: A Reader, ed. Lynn Meskell (Hoboken, NJ: Wiley-Blackwell, 2015), 27. The paper provides an extensive literature review.

21 Michael N. Barnett and Martha Finnemore, Rules for the World: International Organizations in Global Politics (Ithaca, NY: Cornell University Press, 2004); John G. Hadwen and Johan Kaufmann, United Nations Decision Making, 3rd ed. (Alphen aan den Rijn: Sijthoff \& Noordhoff, 1980); Jarle Trondal et al., Unpacking International Organisations: The Dynamics of Compound Bureaucracies (Manchester: Manchester University Press, 2010).

22 As Peter M. Haas explains, the knowledge-based interpretation as a reaction to uncertainty, or, simply speaking, a set of problems a state actor sees itself confronted with, is essential to the creation of institutional solutions on a state and, in the case of the UN, inter-state level; Peter M. Haas, "Introduction: Epistemic Communities and International Policy Coordination", International Organization 46, no. 1 (1992): 3-4, https://doi.org/10.1017/S0020818300001442; Maurel, Histoire de l'UNESCO, 261-75. 
the local, national and international sphere. ${ }^{23}$ International organisations, and the experts employed in their service, formed a global communication elite in control of information and knowledge about both their member states and the organisations' inner workings as the top nodes of a "long distance network". ${ }^{24}$ To contribute to broaden the empirical base for understanding how this expert hegemony was produced and reproduced on a daily basis, this book looks into the work behind the scenes and into the bureaucratic and administrative conditions and into the offices of the staff of UNESCO's headquarters in Paris, UNESCO's Addis Ababa office, the offices of IUCN in Morges, ICOMOS in Paris and ICCROM in Rome, and those of the Ethiopian counterparts.

In order to become compatible to the UN system and the financial and knowledge resources available through it, Ethiopia needed to provide the language and institutional counterparts for collaboration on the operational level. International experts and Ethiopians trained abroad ensured the compatibility for the development aid programmes. The heritage expertise commissioned through UNESCO rendered an existing network of heritage sites and their history into a language that could be computed by the operational guidelines of the international bureaucracies. This serves as an example for the specific, internationalist style of knowledge production which considerably shaped the emerging bureaucratic infrastructure in many countries, while the power relations and the knowledge production related to the development discourse remained anchored in the headquarters of the UN agencies, in Rome, Paris and New York. ${ }^{25}$

23 Ibid.; Wolfram Kaiser, Writing the Rules for Europe: Experts, Cartels, and International Organizations (Basingstoke: Palgrave Macmillan, 2014); Davide Rodogno, Bernhard Struck, and Jakob Vogel, Shaping the Transnational Sphere: Experts, Networks, and Issues from the 1840s to the 1930s (New York: Berghahn Books, 2015); Sandrine Kott, "International Organizations: A Field of Research for a Global History”, Zeithistorische Forschungen/Studies in Contemporary History 8 (2011): 446-50, https://doi.org/10.14765/zzf.dok-1641.

24 Gunnar Folke Schuppert, Wege in die moderne Welt: Globalisierung von Staatlichkeit als Kommunikationsgeschichte (Frankfurt; New York: Campus, 2015), 39; Frederik Schulze, "ANT und Globalgeschichte: Ein erster Eindruck", in Techniken der Globalisierung: Globalgeschichte meets Akteur-Netzwerk-Theorie, ed. Debora Gerstenberger and Joël Glasman (Bielefeld: transcript, 2016), 281-90, https://doi.org/10.14361/9783839430217-013; Rosemary O'Leary, "The Bureaucratic Politics Paradox: The Case of Wetlands Legislation in Nevada”, Journal of Public Administration Research and Theory 4, no. 4 (1994): 443-67.

25 I would argue that it is conceptually fuzzy who exactly can be considered a Western or nonWestern expert. Most regularly, African elites with European training were acting as cultural brokers, even though they were not necessarily regarded as such in Europe; Martin Rempe, Entwicklung im Konflikt: die EWG und der Senegal, 1957-1975 (Wien; Köln; Weimar: Böhlau, 2012), 61, 239-40; Philipp H. Lepenies, "Lernen vom Besserwisser: Wissenstransfer in der "Entwicklungshilfe” aus historischer Perspektive”, in Entwicklungswelten: Globalgeschichte der Entwick- 
The new international order forming in the 1960s was underpinned by various internationalisms, which African voices constituted to a significant degree. ${ }^{26}$ With the rise of the new multilateral and Third-World internationalisms, political leaders worldwide had to reformulate the national identities they claimed to represent, in a more far-reaching global process. In this context, African intellectuals acted as representatives of sovereign, independent nation states and actualised the discourse of a particular African identity and intellectuality. Various projects emerged to rewrite African history as Africa's own history, with some of them casting African history as a decidedly un-modern, un-industrial history, and eventually interpreting the postcolonial period as African enlightenment. ${ }^{27}$ From today's viewpoint, this process was in many ways not an emancipation but a renewal of the mechanism of producing knowledge about Africa within the Western academic system, rendering the supposed act of emancipation into a rewriting of African history as a universal, Eurocentric history in the service of new political elites. ${ }^{28}$ The re-appropriation and emancipation of heritage-

lungszusammenarbeit, ed. Hubertus Büschel and Daniel Speich (Frankfurt a. M.: Campus, 2009), 49-54; Andrea Rehling, "Kosmopolitische Geschichtsschreibung und die Kosmopolitik des UNESCO Weltkultur- und Naturerbes", in Bessere Welten: Kosmopolitismus in den Geschichtswissenschaften, ed. Isabella Löhr and Bernhard Gißibl (Frankfurt a.M.: Campus, 2017), 389-92; Rist, History of Development, 74. Although it is fruitful to see them as a group, it is important to understand that expert communities are far from being homogenous, as the individuals in them have different backgrounds, motives, incentives and levels of agency. While I don't provide a detailed comparison of the biographical background of the experts, I came across Indian, Swiss, Polish, British conservators and education experts, all working in Ethiopia as "foreign experts". It would be enlightening, for example, to further investigate the colonial trajectories in the experts' biographies, meaning people who received expert status in a colonial context, regardless of the provenance.

26 Byrne, Mecca of Revolution; Christoph Kalter, The Discovery of the Third World: Decolonization and the Rise of the New Left in France, c. 1950-1976 (Cambridge: Cambridge University Press, 2016).

27 Bahru Zewde and Congrès international des historiens africains, eds., Society, State, and Identity in African History (Addis Ababa; Bamako: Forum for Social Studies, 2008); Messay Kebede, "Eurocentrism and Ethiopian Historiography: Deconstructing Semitization", Intejethistud International Journal of Ethiopian Studies 1, no. 1 (2003): 1-19; Andreas Eckert, "Afrikanische Intellektuelle und Aktivisten in Europa und die Dekolonisation Afrikas", Geschichte und Gesellschaft 37, no. 2 (2011): 244-74; Brenda Cooper and Robert Morrell, "The Possibility of Africa-Centred Knowledges”, in Africa-Centred Knowledges: Crossing Fields and Worlds, ed. Brenda Cooper and Robert Morell (Woodbridge, Suffolk: James Currey, 2014), 2-6.

28 Bogumil Jewsiewicki and V.Y Mudimbe, "Africans' Memories and Contemporary History of Africa”, History and Theory 32, no. 4 (1993): 1-11, https://doi.org/10.2307/2505629; Paulin J. Hountondji, "Knowledge of Africa, Knowledge by Africans: Two Perspectives on African Studies”, RCCS Annual Review 1 (2009): 121-31, https://doi.org/10.4000/rccsar.174. 
making therefore formed a relevant issue in the process of decolonisation-having a national heritage meant having a national identity and belonging to the community of sovereign nation states. ${ }^{29}$ UNESCO served most prominently as a framework to promote the importance of history and heritage as a strategy for empowerment and fostering the nascent national identities of the new member states in the era of decolonisation; in other words, providing development-aid for nation-building. ${ }^{30}$ The General History of Africa, initiated under the first African Director General of a UN-agency, Amadou-Mahtar M'Bow, was the outcome most indicative of this trend. ${ }^{31}$ With the Ethiopian example, I support the critical analysis others have provided so far on the role of African historiography, inventing traditions, and as a part of it, identifying cultural and natural heritage to augment national identity. Looking through the lens of UNESCO, in the files I studied to understand UNESCO's cultural and natural heritage politics during the $60 \mathrm{~s}$ and 70s, I found evidence of similar entangled histories of universal heritage and national identity like that of Ethiopia in several other countries at the time, for example Egypt, Indonesia, Burma. However, I have only included references to other national contexts where they serve a comparative purpose. The main focus in this book will be on the Ethiopian case study, seen as an example of a global trend towards a growing importance of national identities. This trend occurred between theoretical and practical internationalisms with the institutionalisation of national heritage as an integral part of the internationalist project that would result in the 1972 UNESCO World Heritage Convention and the World Heritage List of 1978 onward.

The history of the concepts of "heritage" and "conservation"32 as universal principles is one that originates within the context of European and US postwar internationalism at a time when there was an ever-increasing, all-encom-

29 Andreas Eckert, "Ethnizität und Nation in der Geschichtsschreibung zu Afrika seit 1960", Comparativ: Zeitschrift für Globalgeschichte und vergleichende Gesellschaftsforschung 11, no. 4 (2001): 17-30.

30 Andrea Rehling, "Universalismen und Partikularismen im Widerstreit: Zur Genese des UNESCO-Welterbes”, Zeithistorische Forschungen/Studies in Contemporary History 8 (2011): 414-36, https://doi.org/10.14765/zzf.dok-1644.

31 Unesco International Scientific Committee for the Drafting of a General History of Africa, General History of Africa, vol. 1-8 (Paris; Berkeley; Oxford: Heinemann; UNESCO; University of California Press, 1993).

32 A concise summary of the variation of the interpretation of the term heritage can be found in: Astrid Swenson, "'Heritage", "Patrimoine” und "Kulturerbe”: Eine vergleichende historische Semantik”, in Prädikat 'Heritage': Wertschöpfungen aus kulturellen Ressourcen, ed. Dorothee Hemme (Berlin: Lit-Verlag, 2007), 53-74. 
passing emphasis on the symbolic inscription of things as heritage all over the Western world. ${ }^{33}$ In this history, UNESCO acted as the main driving force behind a global engagement with these and other concepts related to heritage, such as authenticity - taken to be the guiding principle behind the conservation of historic monuments and landscapes in a specific national context - thereby detaching them from the French and Anglo-Saxon traditions in which they arose. Such traditions have evolved in an entangled manner with scientific disciplines and specialised professions such as art history, archaeology for cultural heritage, as well as biology and geography for natural heritage. With the nineteenth century European imperial expansions, the "discovery" of treasures and adventures became a systematic team effort between these disciplines and politics, approaching the extra-European territories in search of monumental remains of narratives that formed part of the Western historiography, such as the Levant and the Horn of Africa.

World Heritage, as defined in the UNESCO World Heritage Convention, however, was a global phenomenon, not unilaterally originating and spreading from Europe but engaging with and reacting to emerging nationalism in developing countries. The public debate about the restitution of African cultural goods from European national museums to their places and cultures of origin is an actualised version of debates which originated within UNESCO during the 1970s, and the long-term projects for the conservation of cultural heritage in Ethiopia under the guidance of UNESCO can serve as a case study to illuminate the ambiguity of the debate of African heritage and African cultural property in Western institutions. The understanding that African states and historians did not necessarily find Western involvement in their cultural or natural heritage problematic complicates some of the political positions which call for complete restitution of African objects housed in European museums in no unclear terms. ${ }^{34}$ During the 1960s, Ethiopia simultaneously issued restitution claims to the United Kingdom and Italy, exercised rigorous control of foreign archaeologists excavating Ethiopian historical and pre-historical sites, and cooperated with Italian conservators and French archaeologists, inviting them to be involved in the project of re-writing Ethiopian national history. While neither these restitution cases nor UNESCO's involvement were part of my studies, I believe reading the history of the establishment of Ethiopian national heritage sites with the extensive involvement

33 Markus Tauschek, Kulturerbe: eine Einführung (Berlin: Reimer, 2013), 10-13; Eric Hobsbawm, "Introduction: Inventing Traditions", in The Invention of Tradition, ed. Eric Hobsbawm and Terence Ranger (Cambridge: Cambridge University Press, 1983), 1-14.

34 Felwine Sarr and Bénédicte Savoy, Restituer le patrimoine africain (Paris: Philippe Rey, 2018). 
of UNESCO can provide important historical context and an understanding of the actors, networks and interactions that the global heritage-making entailed.

The concept of universal heritage was related to the discourses of nationalism, imperialism, colonialism and their "principles that aspired to build a totality in which everybody would be included but not everybody would also have the right to include." 35 In practice, this meant that the concepts and scientific methods related to the Western heritage discourse translated into an elaborate and specific set of formal standards for the conservation of natural and cultural heritage, making these academic disciplines and their experts, now labelled conservators, into gatekeepers, who gained relevance from this institutionalised setting, combining a universalist discourse with a worldwide practice. ${ }^{36}$

The study of heritage as part of the development discourse and practice, others have argued, helps to understand memory and heritage-making in the nation state as a global history, and why this process regularly involved external actors and their imaginations of a particular national history and identity. ${ }^{37}$ I want to add to this field of critical heritage studies with a historiography of the operationalisation phase of international organisations during the 1960s, when a renewed outwards expansion of Europe resulted in the application of Western concepts and technologies of heritage on a global scale and consequently integrated heritage in the development discourse, as a way to better the cultural integrity of underdeveloped countries. ${ }^{38}$ Conservators, that is Western heritage experts, positioned themselves as actors and facilitators in a development process that was guided by a strong culturally rooted paradigm. Their discourse and practice was critical for the application of conservation in African countries and the build-up of international conservation policies in new nation states and it is

35 Walter Mignolo, The Darker Side of Western Modernity: Global Futures, Decolonial Options (Durham, NC: Duke University Press, 2011), 160-61.

36 The requirements for the elaboration of standards evolved significantly over time, having today reached a point where it is expected that several years of preparation work are potentially necessary for a site to comply with all the requirements for a successful application; Thomas $\mathrm{M}$. Schmitt, Cultural Governance: zur Kulturgeographie des UNESCO-Welterberegimes (Stuttgart: Steiner, 2011), 368-72.

37 Laurajane Smith, Uses of Heritage (Abingdon, Oxon; New York: Routledge, 2006), 42-43; Aleida Assmann and Sebastian Conrad, "Introduction”, in Memory in a Global Age: Discourses, Practices and Trajectories, ed. Aleida Assmann and Sebastian Conrad (Basingstoke: Palgrave Macmillan, 2010), 2; Kendall R. Phillips and G. Mitchell Reyes, eds., Global Memoryscapes: Contesting Remembrance in a Transnational Age (Tuscaloosa: University of Alabama Press, 2011). 38 David Held, Global Transformations: Politics, Economics and Culture (Stanford: Stanford University Press, 1999), 39. 
key to the analysis of history, politics and the production and instrumentalization of national identity in past and present African states. ${ }^{39}$

Without denying the notion of a Western discourse as a crucial influence in shaping the history of countries constructed as the non-Western "Other”, I want to complicate our understanding of how conservation evolved in a developing country and help explain why heritage presents today one of the most important assets-financially, socially and politically-for many African societies. ${ }^{40}$ Heritage-making, from a state perspective, is not only an institutional and scientific but also a territorialising practice. Heritage can be a legal instrument, regulating ownership over the site in question, and conservation law can legitimise expropriation, an issue of concern especially for agrarian or pastoralist societies and indigenous people, where land-use and land rights are the most pressing. As a result, heritage has to be also seen as a tool of governance, an aspect that is most relevant in developing countries because it allows new argumentation and legitimation for governments to infringe on customary land rights. Heritage, like development, is what Arturo Escobar has described as a "pervasive" 41 discourse and practice, because it runs through all aspects of a society in its implementation, including legislation, land use, institution building, policymaking and identity construction. This aspect of heritage as a governing practice is central to understanding why the development paradigm has politicised heritage even further. As an answer to the numerous works studying heritage culturally, looking at the processes of cultural memory and imagined community that lead to the invention of a collective past, this book delivers a detailed account of bu-

39 Winfried Speitkamp, “”Authentizität” und Nation: Kollektivsymbolik und Geschichtspolitik in postkolonialen afrikanischen Staaten”, in Nationale Mythen - Kollektive Symbole: Funktionen, Konstruktionen und Medien der Erinnerung, ed. Klaudia Knabel, Dietmar Rieger, and Stephanie Wodianka (Göttingen: Vandenhoeck \& Ruprecht, 2005), 225-43.

40 More generally on the "other": Said, Orientalism; Gayatri Chakravorty Spivak, “"Can the Subaltern Speak?": revised edition, from the "History” Chapter of Critique of Postcolonial Reason”, in Can the Subaltern Speak?: Reflections on the History of an Idea, ed. Rosalind C. Morris (New York: Columbia University Press, 2010), 21-78; Homi K. Bhabha, The Location of Culture: With a New Preface by the Author (London; New York: Routledge, 2012); Dipesh Chakrabarty, Provincializing Europe: Postcolonial Thought and Historical Difference (Princeton, NJ: Princeton University Press, 2000); used on specific examples: Marija N. Todorova, Imagining the Balkans (Oxford: Oxford University Press, 2010); Derek Peterson, Kodzo Gavua, and Ciraj Rassool, eds., The Politics of Heritage in Africa: Economies, Histories, and Infrastructures (Cambridge; New York: Cambridge University Press, 2015). Unfortunately, the volume follows a colonial/contemporary distinction which makes it more difficult to generalise the findings.

41 Escobar, Encountering Development, 6. 
reaucratic and institutionalised processes of heritage-making, the varied "on the ground" practice complementing the discourse of heritage. ${ }^{42}$

In my study of Ethiopian national heritage I drew on two sets of sources in particular: First, I relied on images of Ethiopian heritage, as they circulated in tourism promotion material and government publications, to gain a better understanding of the imaginations, visual representations and ideas that were constructed in the service of the nation state and aspiring national elites. Second, I took a close look at official correspondence and mission reports to comprehend the making of heritage, concrete actions, and the bureaucratic and legal processes created around and behind heritage which significantly shape the actual outcome and production of heritage. This includes documents of the World Heritage Committee and the respective departments within UNESCO that provided assistance and reviewed nomination files (changing names and organisational structure several times over the course of the research period), further documents from the ICCROM, the International Council on Monuments and Sites (ICOMOS), and the International Union for the Conservation of Nature and Natural Resources (IUCN), the agents carrying out operations in Ethiopia (especially UNDP), Ethiopian state-affiliated actors (the Ethiopian delegation in Paris and the government executive, i.e. ministries for culture and sports, and agriculture and environment), as well as research institutions, the Institute of Ethiopian Studies at Addis Ababa University (IES) and the Institut éthiopien d'études et de recherches, the preceding institution of today's Centre français des études éthiopiennes (CFEE).

However, not all these perspectives were equally accessible during the time of my research. The UNESCO archives had extensive holdings concerning all aspects of UNESCO's relations with Ethiopia, allowing insight also in the activities of UNDP, ICOMOS and IUCN. The country, department and issue-based files contain mainly correspondence and notes as well as reports, enabling a deeper look into the everyday work of the UNESCO secretariat and the connections and net-

42 Camila del Mármol, Marc Morell, and Jasper Chalcraft, "Of Seduction and Disenchantment: An Approach to the Heritage Process", in The Making of Heritage: Seduction and Disenchantment, ed. Camila del Mármol, Marc Morell, and Jasper Chalcraft (New York: Routledge, 2015), 3; David Lowenthal, The Heritage Crusade and the Spoils of History (Cambridge; New York: Cambridge University Press, 1998); Eric Hobsbawm and Terence Ranger, eds., The Invention of Tradition (Cambridge: Cambridge University Press, 1983); Aleida Assmann, Erinnerungsräume: Formen und Wandlungen des kulturellen Gedächtnisses, 3rd ed. (München: C.H. Beck, 2006); Benedict Anderson, Imagined Communities: Reflections on the Origin and Spread of Nationalism, revised ed. (London; New York: Verso, 2006). 
works of the individual departments. ${ }^{43}$ This complemented the official documents, such as reports of meetings and the Director General, of which UNESCO provides a large body of files in digital form, including films and photographs, and many files concerning the World Heritage Programme from its inception, including Committee meetings and the documentation for all World Heritage sites. IUCN, ICCROM and ICOMOS all have archives or libraries that can be accessed and which I visited, which contain some grey literature as well as photographic material that is otherwise unavailable, but they do not keep regular archives that enable an investigation of the institutional backstory through correspondences and internal reports. No such contact or entry point is available in the case of UNDP at all. As a matter of fact, a particular closed-gate politics is practiced, making the institution unavailable for historical inquiry in a direct avenue. I had to rely on copies and transcripts which were part of files I accessed at UNESCO and Ethiopian archives. Combining all of these sources, I achieved a vivid image of the process-driven nature and a day-to-day practice in the offices and field offices, an on the ground view into the UN during the 1960 s. $^{44}$

Despite the main official language of Ethiopia being Amharic, many government affairs were conducted in English and I used these English-language sources for my analysis. Unfortunately, the National Archives of Ethiopia only holds some material from the imperial ministries up to 1974, and the existing material is scarce. For example, the complete file on the Lalibela project, which went on for several years, is comprised of only twelve individual documents. The two conservation authorities, the Authority for Research and Conservation of Cultural Heritage (ARCCH) and the Ethiopian Wildlife Conservation Authority (EWCA), have internal archives and libraries that I was permitted to access. The Library of the Institute of Ethiopian Studies and the Kennedy Library, both part of Addis Ababa University, were a fruitful source of Ethiopian government publications and tourism-related material. Other archives and libraries I visited to obtain Ethiopian government publications, tourism promotion press material and re-

43 I would like to give a special mention of one of the most crucial categories of sources this study is built on: UNESCO (and to a small extent other UN agencies) mission reports. Published reports are accessible through the online repositories of the UN agencies; they are numerous and very dense in terms of content. They contain invaluably operational details and technical information about development projects and the cooperation between international organisations and national governments. They also usually include expert evaluations, which reveal mindsets and expectations of international experts. I argue they represent a body of literature in its own right, and that more methodological debate on this literature would be desirable.

44 Kott, "International Organizations”, 1-2. 
search works from the 1960s-1980s include the New York Public Library, ${ }^{45}$ the Hiob Ludolf Center for Ethiopian Studies at Hamburg University, the Staatsbibliothek zu Berlin, ${ }^{46}$ the School of Oriental and African Studies (SOAS) Archives and Library ${ }^{47}$ and the Berhanu Abebe Library of the CFEE in Addis Ababa.

To try bring some balance into the lack of Ethiopian government documents versus the extensive holdings of the UNESCO archives, I used academic and other publications, such as travel guides and personal memoirs, written during the period in question, the 60s, on the topics of heritage, conservation and Ethiopia. It is important for all this literature published in the 1960s and 1970s to be read critically and they function more as a primary source here than as secondary source or literature reference. The works of Margery Perham, Donald Levine, John Markakis and Nega Ayele, Richard and Sylvia Pankhurst (to name just a few), all renowned scholars or stateswomen at the time, contain many views and paradigms, among them essentialist, colonialist and racist ones, that are extremely problematic from today's viewpoint. This book is based on research efforts with a focus on providing an overview over the manifold types of sources that can be useful for understanding the relationships and processes occurring between countries and international organisations. And while for many of the sources cited here it would be desirable to go deeper into their individual analysis, regarding the context of their production, authorship and whereabouts, I understand this work as a proposition on how to write African history as global history, pairing disparate types of documents and sources so as to open up many new lines of inquiry.

As an addition to my analysis, I had the opportunity to conduct a few personal interviews with experts involved in the Ethiopian World Heritage sites, namely Yonas Beyene, from the Ethiopian Authority for Research and Conservation of Cultural Heritage and former Ethiopian delegate to the World Heritage Committe, Prof. Dr. Hans Hurni, Professor for Geography in Berne, Switzerland, who worked as an expert in wildlife conservation in Ethiopia for over twenty years and who was personally involved in the nomination process of the Ethiopian natural heritage sites, especially the Simien National Park; and Dr. Jean Renaud Boisserie, Director des Recherches at the CFEE. Most helpful information

45 Particularly the Schomburg Center for Research in Black Culture and the Science and Industry Library, which had a collection of all Ethiopian development plans.

46 The Staatsbibliothek holds some years of the Ethiopian Herald.

47 The SOAS Archives hold several personal files of British researchers and diplomats, documenting their activities in Ethiopia, including confidential reports and private correspondence with people in Ethiopia. 
regarding the history of tourism in Ethiopia was provided to me in an email exchange, and a short personal meeting, with the journalist Arefaynie Fantahun.

Ethiopia officially uses the Ethiopian calendar, but all dates have been converted to the European calendar format for continuity. As regards the transliteration of Ethiopian names and terms, I followed the English or French transcription used in each individual primary or secondary source, which may have resulted in some inconsistencies.

\section{Chapter Synopses}

1. Tourism was part of economic development planning in African countries, building on colonial images of Africa; culture and wildlife were considered economic resources; cultural tourism and conservation of monuments for tourism were part of UNESCO's programme in the 1960s; in cultural tourism projects, the development paradigm was merged with a tourist gaze on cultural and natural heritage in developing countries; tourism development plans in Ethiopia resulted in a selection of heritage sites most suitable for tourism; their image and symbolic value was amplified through tourism promotion.

2. Ethiopian nationalism relied on the Aksumite paradigm, stressing Ethiopian exceptionalism and the need for a unified Greater Ethiopia; a distinct visual language of Ethiopian nationalism emerged, of which historical monuments formed a key part; Western narratives and imaginations of Ethiopia and archaeological research interests of expatriates supported the construction of an official Ethiopian national identity; Ethiopian heritage served representation and communication in an international and Pan-African context; cultural assimilation politics fostered an Amhara-dominant national identity.

3. Western Ethiopian Studies were established in the nineteenth century; the 60s witnessed a renewed academic and state effort of re-writing Ethiopian history and the building-up of state institutions for research and administration of history and heritage; diplomacy and foreign research interests were crucial for the operations of state institutions, most researchers were foreigners in the beginning; through UNESCO, numerous conservation and heritage-making projects took place, providing the administrative and formal prerequisites for Ethiopian World Heritage nominations.

4. Some examples show that research and conservation projects depended on local actors and their knowledge, who in turn tried to reap benefits from the collaboration; heritage projects were characterised by a structural marginalisation of traditional conservation knowledge; the international standards and scientific principles and their universalist underpinning had a strong normative effect on heritage traditions; the colonial and imperial legacies of international 
heritage conservation were embedded in the international organisations; severe land use conflicts arose from claims to heritage, to the detriment of inhabitants of heritage sites and their surroundings.

5. The bureaucratic side of the implementation of heritage followed other paradigms and rules; strategic goals were influencing the cooperation of UNESCO and Ethiopia on both sides; Addis Ababa gained location value as a African diplomatic hub; Ethiopia was envisaged as voice for other African countries in the UN and UNESCO; foreign advisors and foreign aid were part and parcel for state modernisation in Ethiopia; personal connections and education background of Ethiopians in UNESCO were vital for project orientation and implementation; Ethiopia was chosen as UNDP model country for large-scale projects, with the seven-year heritage project as first examples. 